\title{
DYNAMICS OF FREQUENCY AND PECULIARITIES OF THE STRUCTURE OF CONGENITAL MALFORMATIONS IN SOUTH UKRAINE (MONITORING STUDY)
}

\author{
O. Lanovenko \\ KHERSON STATE UNIVERSITY, KHERSON, UKRAINE
}

\begin{abstract}
Background. In Ukraine, the unfavorable demographic situation makes monitoring of the birth rate of
\end{abstract} children with congenital malformations urgent issue to identify regional features of epidemiology and develop methods for prenatal diagnosis and prognosis.

Objective. Objective of this study is to characterize the frequency dynamics, to identify structural features of congenital malformations of newborns in Kherson region over a 20-year period (2000-2019) and to compare the prevalence of various nosological forms of malformations in the region, in Ukraine and in European countries.

Methods. Research methods: epidemiological, medical-statistical.

Results. In Kherson region, the average frequency of congenital malformations over the past 20 years is:

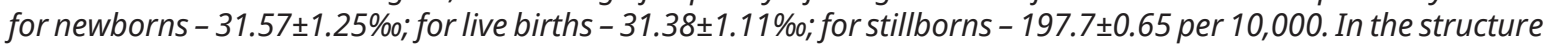
of defects, cardiovascular malformations are leading (31.77\%), musculoskeletal malformations (25.14\%), genital malformations (17.5\%). Increased prevalence of developmental anomalies in the region is mainly associated with an increase in the frequency of model malformations recorded by EUROCAT $(r=0.69, p<0.05)$. The increase in the total frequency of congenital malformations is caused by increased number of births of children with cardiovascular defects (by 4.67\%o), genital defects (by 1.21\%o), other congenital malformations (by 1.55\%o), multiple malformations (by $0.37 \%$ ).

Conclusion. Monitoring results showed an increase in congenital malformations incidence in Kherson region over a 20-year period by $7.94 \%$ possibly caused by population decline due to negative natural and mechanical growth. The prevalence of hereditary defects is at the same level. The frequency of some nosological forms significantly exceeds in the region compare to that in Ukraine and Europe: cardiovascular defects - in 1.5 times, genital malformations - in nearly 3 times, musculoskeletal defects - almost twice.

KEYWORDS: congenital malformations; chromosomal pathology; population; newborns.

\section{Introduction}

An unfavorable demographic situation in Ukraine (decrease in birth rate, high mortality and disability, negative natural population growth) necessitates monitoring of the genetic load of human populations, which averages 50-70 per 1000 newborns (5-7\%): congenital malformations account for $2-5 \%$, hereditary diseases $-1.5 \%$ (chromosomal $-0.5 \%$, genetic $1 \%)$, diseases with a significant hereditary predisposition -3-3.5\% [1]. Monitoring the birth rate of children with congenital malformations is necessary for identifying the epidemiology of its various nosological forms and for development of methods for prenatal diagnosis and prognosis [2]. According to current concepts, congenital malformations are defects in morphogenesis in the early period of fetal life of genetic and/or epigenetic etiology [3].

\footnotetext{
*Corresponding author: Olena Lanovenko - Assistant Professor, Kherson State University, 73 000, Ukraine. E-mail: lanovenko2708@gmail.com
}

The spectrum of mutations in genes that control the form-developing processes in embryogenesis may be ethno specific. Therefore, during monitoring of the prevalence and structure of malformations, the influence of ethnic factors should be taken into account, as well as not only epidemiological, but also genetic and demographic aspects [4,5].

Thus, the aim of the study was to define the dynamics of frequency, to identify the structural features of congenital malformations of newborns in Kherson region over a 20-year period (2000-2019) and to compare the prevalence of various nosological forms of congenital malformations in the region, Ukraine and European countries.

\section{Methods}

The study was conducted in Kherson region, covering all 18 territorial-administrative regions. For the analysis, the 20-year observation period (2000-2019) was divided into five-year 
periods (2000-2004, 2005-2009, 2010-2014, 2015-2019).

The objects of the study were newborns (live and stillborn) with isolated and multiple congenital malformations, which were born to residents of Kherson region during the study period. The obtained material was analyzed using the registration of all forms of malformations included in the list of ICD-10 of section $\mathrm{Q}$ in order to assess their frequency and structure.

When conducting a comparative analysis of the incidence of malformations in populations, it is necessary to take into account standard markers - those forms of them that are often encountered and are unambiguously diagnosed by doctors of all specialties in one age cohort. Such forms have a well-defined phenotype and are well diagnosed at birth. These are: multiple congenital malformations and compulsory model defects (Q00-Q99). Long-term monitoring of populations for such markers makes it possible to assess the prevalence and dynamics of malformations and conduct their comparative analysis in populations, which is one of the tasks of the European international register EUROCAT (European surveillance of congenital anomalies).

Since the number of abortions is not large enough to have a significant impact on the prevalence of defects, calculations for this indicator were carried out in a cohort of newborn children. Most cases of malformations among all pregnancies occur in children born alive; therefore, it is the assessment of the dynamics of their prevalence in this cohort, and not all births, that is the most acceptable form of analysis of epidemiological data [6].

The prevalence of malformations was calculated as the ratio of the number of newborns with congenital malformations to the total number of newborns multiplied by 1000 (\%). Similar calculations were carried out in cohorts of live and stillborn children. The data for a comparative analysis of the frequencies of congenital malformations were taken from the open official website of the European register of the international organization EUROCAT [http://www.eurocat-network.eu].

The theoretical indicator of the number of hereditary congenital malformations was calculated as the sum of cases of chromosomal pathology of living children and half of the remaining part of congenital malformations (without chromosomal diseases), since it is established that about half of cases of congenital malformations (regardless of clinical manifestation) are caused by genetic factors [7].

Statistical processing of the research results was carried out using MS Excel: determining of the average value, error of the average value, growth rate. Using the Statistica 6.0 software package, the statistical connection of features was determined by the Spearman rank correlation method.

\section{Results}

In total, in 2000-2019, 222,191 newborn babies were born in Kherson region; 220,067 of them were live-born and 2,124 still-born. Congenital malformations were found in 7015 newborns, including 6973 live births and 42 stillborns. The obtained data allowed estimating the population frequency of congenital malformations in children of Kherson region, which is: for newborns $-31.57 \pm 1.25 \%$; for live births $31.38 \pm 1.11 \%$; for stillbirths $-197.7 \pm 0.65$ per 10,000 . Based on the data of the Regional Department of Statistics in Kherson region, the average annual number of live births in the region for the last 20 years has been calculated, which is 11,003 children (with an average statistical deviation of up to $5 \%$ ).

Theoretical calculations of the prevalence of congenital malformations in the region show that approximately 556 newborns (5\%) may be born with signs of congenital pathology. Since the contribution of the genetic component to the structure of malformations is on average about $50 \%$ (the other half is a consequence of teratogenesis) [8], thus for Kherson region the hereditary component of malformations is expected at the level of 278 people per year ( $2.5 \%$ of the number of newborns). Actual calculations of the prevalence of congenital malformations are presented in Table 1.

According to Table 1, with the decrease in the birth rate in the region, the prevalence of congenital malformations is rising (from 20.6\% in 2004 to $37.6 \%$ in 2017) and on average over a 20 -year period was $31.4 \%$. Among all congenital malformations, the actual number of cases of hereditary forms (181 people per year) turned out to be lower than the theoretically calculated indicator (278 people per year); it did not undergo significant changes in recent years and averaged within $52 \%$ of all anomalies; this testifies the stable level of mutation process in the region. But in a long-time tendency, the share of hereditary forms is gradually increasing: in 2000 it was $1.29 \%$, in 2019 it was $1.62 \%$. There is a gradual increase in the 
frequency of multiple malformations: from 0.29 to $0.66 \%$.

Since the incidence of neonatal malformations and spontaneous miscarriages correlates with their prevalence among live births, we analyzed the dynamics of nosological forms of congenital anomalies in the last cohort (Table 2).

According to Table 2 in the structure of congenital malformations malformations of the cardiovascular system are leading $(31.77 \%$ of all cases, an average annual increase of $9.1 \%$ ), the frequency of which is constantly increasing from 5.1 to $9.93 \%$ on average over the past 20 years. Congenital malformations of the musculoskeletal system $(25.14 \%$ of all cases, the prevalence slightly decreases from 7.93 to 6.13 and averages 7.35) are the second. Stably high frequency of malformations of the genital organs (on average 5.23\%; in the structure $17.5 \%$ of the total number of cases).
There is a gradual increase in the frequency of multiple malformations - from 0.29 to $0.66 \%$, and a slight increase in their share in the overall structure of anomalies (by $0.8 \%$ ). The prevalence of chromosomal abnormalities $(1.0-1.17 \% 0)$ is characterized by relative stability, which confirms the previous assumption about the constancy of the level of the mutation process in the region.

The greatest lethality is caused by defects of the central nervous system (Q00-Q07), in particular anencephaly, multiple congenital malformations (Q89.7) and chromosomal abnormalities (Q90-Q99).

Then a comparative analysis of the prevalence of congenital malformations in Kherson region was carried out regarding Ukraine and European countries (according to the international register EUROCAT) (Table 3). It has been noted that there is a significant increase in the frequency of malformations of the car-

Table 1. Dynamics of congenital malformations prevalence (Kherson region, 2000-2019)

\begin{tabular}{|c|c|c|c|c|c|c|c|c|c|c|c|}
\hline \multirow{5}{*}{ Years } & \multirow{5}{*}{$\begin{array}{l}\text { Number } \\
\text { of live } \\
\text { births }\end{array}$} & \multicolumn{10}{|c|}{ Congenital malformations } \\
\hline & & \multirow{4}{*}{ Total } & \multirow{4}{*}{$\begin{array}{c}\text { Frequen- } \\
\text { cy, } \% \text { o }\end{array}$} & \multicolumn{8}{|c|}{ Genetically determined congenital malformations: } \\
\hline & & & & \multicolumn{5}{|c|}{ cases of chromosomal pathology } & \multirow{3}{*}{$\begin{array}{l}\text { total } \\
\text { geneti- } \\
\text { cally } \\
\text { deter- } \\
\text { mined }\end{array}$} & \multicolumn{2}{|c|}{ part, \% } \\
\hline & & & & \multirow[b]{2}{*}{$\begin{array}{l}\text { Q90- } \\
\text { Q99 }\end{array}$} & \multicolumn{4}{|c|}{ of them: } & & \multirow{2}{*}{$\begin{array}{c}\text { from } \\
\text { congenital } \\
\text { malforma- } \\
\text { tions }\end{array}$} & \multirow{2}{*}{$\begin{array}{l}\text { from } \\
\text { live } \\
\text { births }\end{array}$} \\
\hline & & & & & Ds & Ps & Es & Ts & & & \\
\hline 2000 & 10184 & 255 & 25.0 & 8 & 8 & - & - & - & 131.5 & 51.6 & 1.29 \\
\hline 2001 & 9757 & 243 & 24.9 & 9 & 9 & - & - & - & 126.0 & 51.9 & 1.29 \\
\hline 2002 & 9972 & 280 & 28.1 & 11 & 8 & - & 1 & - & 145.5 & 52.0 & 1.46 \\
\hline 2003 & 10502 & 216 & 20.9 & 15 & 14 & - & - & - & 115.5 & 53.5 & 1.10 \\
\hline 2004 & 10363 & 201 & 20.6 & 8 & 5 & - & - & - & 104.5 & 52.0 & 1.00 \\
\hline 2005 & 10150 & 307 & 30.2 & 11 & 7 & 1 & - & 1 & 159.0 & 51.8 & 1.57 \\
\hline 2006 & 11475 & 397 & 34.6 & 13 & 13 & - & - & - & 205.0 & 51.6 & 1.83 \\
\hline 2007 & 11570 & 444 & 38.4 & 21 & 18 & 3 & - & - & 232.5 & 52.4 & 1.79 \\
\hline 2008 & 12473 & 556 & 44.6 & 18 & 16 & 1 & - & 1 & 287.0 & 51.6 & 2.30 \\
\hline 2009 & 12323 & 384 & 31.2 & 21 & 18 & 1 & 1 & - & 202.5 & 52.7 & 1.64 \\
\hline 2010 & 12388 & 391 & 31.6 & 18 & 13 & - & 1 & - & 204.5 & 52.3 & 1.65 \\
\hline 2011 & 12085 & 418 & 34.6 & 15 & 9 & 1 & - & - & 216.5 & 51.8 & 1.79 \\
\hline 2012 & 12643 & 428 & 33.8 & 16 & 14 & - & - & - & 222.0 & 51.9 & 1.76 \\
\hline 2013 & 12300 & 388 & 31.5 & 15 & 15 & - & - & - & 201.5 & 51.9 & 1.64 \\
\hline 2014 & 12308 & 433 & 35.2 & 11 & 10 & - & - & - & 222.0 & 51.3 & 1.80 \\
\hline 2015 & 11372 & 352 & 31.0 & 17 & 13 & - & 2 & - & 184.5 & 52.4 & 1.62 \\
\hline 2016 & 10769 & 350 & 32.5 & 11 & 9 & - & 2 & - & 180.5 & 51.6 & 1.68 \\
\hline 2017 & 9964 & 375 & 37.6 & 4 & 3 & - & - & - & 189.5 & 50.5 & 1.90 \\
\hline 2018 & 9095 & 293 & 32.2 & 13 & 12 & - & 1 & - & 153.0 & 52.2 & 1.68 \\
\hline 2019 & 8374 & 262 & 31.3 & 9 & 9 & - & - & - & 135.5 & 51.7 & 1.62 \\
\hline$M$ & 11003.4 & 348.65 & 31.4 & 13.2 & 11.2 & 0.4 & 0.4 & 0.1 & 180.9 & 51.9 & 1.62 \\
\hline$m$ & 281.48 & 20.15 & 1.28 & 1.02 & 0.9 & - & - & - & 10.36 & 0.13 & 0.065 \\
\hline
\end{tabular}

Note: Ds - Down syndrome; Ps - Patau syndrome; Es - Edwards syndrome; Ts - Turner syndrome. 
Table 2. Dynamics of the frequency and structure of congenital malformations of compulsory registration (Q00-Q99) among live births in Kherson region

\begin{tabular}{|c|c|c|c|c|c|c|c|c|}
\hline \multirow[b]{2}{*}{$\begin{array}{l}\text { Form CM (patient's } \\
\text { medical record-10) }\end{array}$} & \multirow[b]{2}{*}{ Units } & \multicolumn{4}{|c|}{ Monitoring periods (years) } & \multirow{2}{*}{$\begin{array}{c}\text { On } \\
\text { average } \\
\text { over } \\
20 \text { years }\end{array}$} & \multirow[b]{2}{*}{ Rank } & \multirow{2}{*}{$\begin{array}{c}\text { Average } \\
\text { increase } \\
\text { rate, \% }\end{array}$} \\
\hline & & $\begin{array}{l}2000- \\
2004\end{array}$ & $\begin{array}{l}2005- \\
2009\end{array}$ & $\begin{array}{l}2010- \\
2014\end{array}$ & $\begin{array}{l}2015- \\
2019\end{array}$ & & & \\
\hline \multicolumn{9}{|c|}{ Congenital malformations: } \\
\hline $\begin{array}{l}\text { Nervous system } \\
\text { (Q00-Q07) }\end{array}$ & $\begin{array}{c}\text { abs. } \\
\% 0 \\
\%\end{array}$ & $\begin{array}{l}7.8 \\
0.77 \\
3.40 \\
\end{array}$ & $\begin{array}{l}10,6 \\
0,93 \\
2,62 \\
\end{array}$ & $\begin{array}{l}7,8 \\
0,64 \\
2.01 \\
\end{array}$ & \begin{tabular}{c|}
7.2 \\
0.73 \\
2.34 \\
\end{tabular} & $\begin{array}{l}8.35 \\
0.76 \\
2.59\end{array}$ & 8 & $\begin{array}{l}+0.55 \\
+0.05 \\
-0.81\end{array}$ \\
\hline $\begin{array}{l}\text { Ear. face and neck } \\
\text { (Q10-Q18) }\end{array}$ & $\begin{array}{c}\text { abs. } \\
\% 0 \\
\% \\
\end{array}$ & $\begin{array}{l}1.8 \\
0.18 \\
0.78 \\
\end{array}$ & $\begin{array}{l}5.0 \\
0.44 \\
1.24 \\
\end{array}$ & $\begin{array}{l}5.6 \\
0.46 \\
1.44 \\
\end{array}$ & $\begin{array}{l}4.4 \\
0.44 \\
1.43 \\
\end{array}$ & $\begin{array}{c}4.2 \\
0.38 \\
1.22 \\
\end{array}$ & 11 & $\begin{array}{l}+2.4 \\
+0.2 \\
+0.44 \\
\end{array}$ \\
\hline $\begin{array}{l}\text { Congenital heart } \\
\text { defects (Q20-Q28) }\end{array}$ & $\begin{array}{c}\text { abs. } \\
\% 0 \\
\% \\
\end{array}$ & $\begin{array}{c}52.0 \\
5.10 \\
22.67 \\
\end{array}$ & $\begin{array}{l}130.0 \\
11.35 \\
32.13 \\
\end{array}$ & $\begin{array}{l}150.6 \\
12.27 \\
38.83 \\
\end{array}$ & $\begin{array}{l}102.8 \\
10.37 \\
33.46 \\
\end{array}$ & $\begin{array}{c}108.9 \\
9.93 \\
31.77 \\
\end{array}$ & 1 & $\begin{array}{l}+56.9 \\
+4.67 \\
+9.1 \\
\end{array}$ \\
\hline $\begin{array}{l}\text { Respiratory (Q30- } \\
\text { Q34) }\end{array}$ & $\begin{array}{c}\text { abs. } \\
\% 0 \\
\%\end{array}$ & $\begin{array}{l}4.0 \\
0.39 \\
1.74 \\
\end{array}$ & $\begin{array}{l}5.2 \\
0.45 \\
1.29\end{array}$ & $\begin{array}{l}5.4 \\
0.44 \\
1.39\end{array}$ & $\begin{array}{l}3.0 \\
0.30 \\
0.98\end{array}$ & $\begin{array}{l}4.4 \\
0.40 \\
1.35 \\
\end{array}$ & 10 & $\begin{array}{r}+0.4 \\
+0.01 \\
-0.39\end{array}$ \\
\hline $\begin{array}{l}\text { Cleft lip with or } \\
\text { without palate } \\
\text { (Q35-Q37) }\end{array}$ & $\begin{array}{c}\text { abs. } \\
\% 0 \\
\%\end{array}$ & $\begin{array}{l}10.0 \\
0.98 \\
4.36\end{array}$ & $\begin{array}{l}11.8 \\
1.03 \\
2.92\end{array}$ & $\begin{array}{l}10.2 \\
0.83 \\
2.63\end{array}$ & $\begin{array}{c}9.2 \\
0.93 \\
3.0\end{array}$ & $\begin{array}{l}10.3 \\
0.94 \\
3.23\end{array}$ & 7 & $\begin{array}{l}+0.3 \\
-0.04 \\
-1.13\end{array}$ \\
\hline $\begin{array}{l}\text { Other congenital } \\
\text { malformations of the } \\
\text { digestive system } \\
\text { (Q38-Q45) }\end{array}$ & $\begin{array}{c}\text { abs. } \\
\% 0 \\
\%\end{array}$ & $\begin{array}{l}10.0 \\
0.98 \\
4.36\end{array}$ & $\begin{array}{l}19.0 \\
1.66 \\
4.70\end{array}$ & $\begin{array}{l}12.4 \\
1.01 \\
3.20\end{array}$ & $\begin{array}{c}10.0 \\
1.0 \\
3.26\end{array}$ & $\begin{array}{l}12.85 \\
1.17 \\
3.88\end{array}$ & 6 & $\begin{array}{l}+2.85 \\
+0.18 \\
-0.48\end{array}$ \\
\hline Genital (Q50-Q56) & $\begin{array}{c}\text { abs. } \\
\% 0 \\
\% \\
\end{array}$ & $\begin{array}{c}41.0 \\
4.02 \\
17.87 \\
\end{array}$ & $\begin{array}{c}61.4 \\
5.36 \\
15.18 \\
\end{array}$ & $\begin{array}{c}64.6 \\
5.26 \\
16.66 \\
\end{array}$ & $\begin{array}{c}62.2 \\
6.27 \\
20.25 \\
\end{array}$ & $\begin{array}{c}57.3 \\
5.23 \\
17.50 \\
\end{array}$ & 3 & $\begin{array}{l}+16.3 \\
+1.21 \\
-0.37 \\
\end{array}$ \\
\hline Limb (Q65-Q79) & $\begin{array}{c}\text { abs. } \\
\% 0 \\
\%\end{array}$ & $\begin{array}{c}80.8 \\
7.93 \\
35.22 \\
\end{array}$ & $\begin{array}{c}99.6 \\
8.70 \\
24.62 \\
\end{array}$ & $\begin{array}{c}81.2 \\
6.62 \\
20.94 \\
\end{array}$ & \begin{tabular}{|c|}
60.8 \\
6.13 \\
19.79 \\
\end{tabular} & $\begin{array}{c}80.6 \\
7.35 \\
25.14 \\
\end{array}$ & 2 & $\begin{array}{c}-0.2 \\
-0.58 \\
-10.08\end{array}$ \\
\hline $\begin{array}{l}\text { Other congenital } \\
\text { malformations } \\
\text { (Q80-Q89) }\end{array}$ & $\begin{array}{c}\text { abs. } \\
\% 0 \\
\%\end{array}$ & $\begin{array}{c}8.8 \\
0.86 \\
3.84\end{array}$ & $\begin{array}{l}34.8 \\
3.04 \\
8.60\end{array}$ & $\begin{array}{l}33.8 \\
2.75 \\
8.72\end{array}$ & $\begin{array}{l}29.4 \\
2.97 \\
9.57\end{array}$ & $\begin{array}{l}26.7 \\
2.41 \\
7.68\end{array}$ & 4 & $\begin{array}{l}+17.9 \\
+1.55 \\
+3.84\end{array}$ \\
\hline $\begin{array}{l}\text { Multiple malforma- } \\
\text { tions } \\
\text { (Q89.7) }\end{array}$ & $\begin{array}{c}\text { abs. } \\
\% 0 \\
\%\end{array}$ & $\begin{array}{l}3.0 \\
0.29 \\
1.31 \\
\end{array}$ & $\begin{array}{l}10.6 \\
0.93 \\
2.62\end{array}$ & $\begin{array}{l}8.2 \\
0.67 \\
2.11 \\
\end{array}$ & $\begin{array}{l}7.4 \\
0.75 \\
2.41 \\
\end{array}$ & $\begin{array}{l}7.3 \\
0.66 \\
2.11 \\
\end{array}$ & 9 & $\begin{array}{r}+4.3 \\
+0.37 \\
+0.80\end{array}$ \\
\hline $\begin{array}{l}\text { Chromosomal } \\
\text { abnormalities } \\
\text { (Q90-Q99) }\end{array}$ & $\begin{array}{c}\text { abs. } \\
\% 0 \\
\%\end{array}$ & $\begin{array}{c}10.2 \\
1.0 \\
4.45\end{array}$ & $\begin{array}{l}16.6 \\
1.43 \\
4.10 \\
\end{array}$ & $\begin{array}{l}14.0 \\
1.18 \\
3.61 \\
\end{array}$ & $\begin{array}{l}10.8 \\
1.08 \\
3.52 \\
\end{array}$ & $\begin{array}{l}12.9 \\
1.17 \\
3.92\end{array}$ & 5 & $\begin{array}{l}+2.7 \\
+0.17 \\
-0.53\end{array}$ \\
\hline $\begin{array}{l}\text { of which Down } \\
\text { syndrome (Q90) }\end{array}$ & $\begin{array}{c}\text { abs. } \\
\% 0 \\
\% \\
\text { from } \\
\text { chrom. }\end{array}$ & $\begin{array}{l}8.8 \\
0.90 \\
90.2\end{array}$ & $\begin{array}{l}14.4 \\
1.26 \\
86.7\end{array}$ & $\begin{array}{l}12.2 \\
0.99 \\
72.7\end{array}$ & $\begin{array}{c}9.2 \\
0.93 \\
85.2\end{array}$ & $\begin{array}{l}11.15 \\
1.02 \\
83.7\end{array}$ & - & $\begin{array}{c}+2.35 \\
+0.12 \\
-6.5\end{array}$ \\
\hline $\begin{array}{l}\text { on average per year } \\
\text { (Q00-Q99) }\end{array}$ & $\begin{array}{c}\text { abs. } \\
\% 0 \\
\%\end{array}$ & $\begin{array}{l}229.4 \\
22.51 \\
100.0 \\
\end{array}$ & $\begin{array}{l}404.6 \\
35.33 \\
100.0 \\
\end{array}$ & $\begin{array}{l}393.8 \\
31.60 \\
100.0 \\
\end{array}$ & $\begin{array}{c}307.2 \\
31.0 \\
100.0 \\
\end{array}$ & $\begin{array}{l}333.8 \\
30.11 \\
100.0 \\
\end{array}$ & - & $\begin{array}{l}+104.4 \\
+7.6\end{array}$ \\
\hline $\begin{array}{l}\text { Other congenital } \\
\text { malformations }\end{array}$ & $\begin{array}{c}\text { abs. } \\
\% 0 \\
\%\end{array}$ & $\begin{array}{c}9.0 \\
0.88 \\
3.67\end{array}$ & $\begin{array}{l}17.2 \\
1.50 \\
4.08\end{array}$ & $\begin{array}{l}25.8 \\
2.10 \\
6.24\end{array}$ & $\begin{array}{l}23.6 \\
2.38 \\
7.13\end{array}$ & $\begin{array}{l}18.9 \\
1.72 \\
5.28\end{array}$ & 4 & $\begin{array}{r}+9.9 \\
+0.84 \\
+1.61\end{array}$ \\
\hline $\begin{array}{l}\text { In total all congeni- } \\
\text { tal malformations }\end{array}$ & $\begin{array}{c}\text { abs. } \\
\% 0\end{array}$ & $\begin{array}{l}238.4 \\
24.06\end{array}$ & $\begin{array}{l}421.8 \\
36.83\end{array}$ & $\begin{array}{l}419.6 \\
33.70\end{array}$ & $\begin{array}{l}330.8 \\
33.36\end{array}$ & $\begin{array}{c}352.7 \\
32.0\end{array}$ & - & $\begin{array}{l}+114.3 \\
+7.94\end{array}$ \\
\hline
\end{tabular}

Note: abs. - the number of cases of birth of a child with congenital malformation of this nosology over 5 years (monitoring period) on average

8 O. Lanovenko 
Table 3. Dynamics of the frequency of various nosological forms of congenital malformations among live births [https://eu-rd-platform.jrc.ec.europa.eu/eurocat/eurocat-data/prevalence_en]

\begin{tabular}{|c|c|c|c|c|c|c|}
\hline \multirow{3}{*}{$\begin{array}{l}\text { Nosological form } \\
\text { of congenital } \\
\text { malformations }\end{array}$} & \multicolumn{2}{|c|}{ Kherson region. \%o } & \multicolumn{2}{|c|}{ Ukraine. \%o } & \multicolumn{2}{|c|}{ EUROCAT. $\% 0$} \\
\hline & \multicolumn{6}{|c|}{ Years: } \\
\hline & $2001-2005$ & 2013-2017 & $2001-2005$ & 2013-2017 & 2001-2005 & 2013-2017 \\
\hline nervous system & 0.87 & 0.93 & $\begin{array}{c}1.006 \\
(0.657-1.475)\end{array}$ & $\begin{array}{c}1.85 \\
(1.615-2.111)\end{array}$ & $\begin{array}{c}1.274 \\
(1.232-1.317)\end{array}$ & $\begin{array}{c}1.162 \\
(1.126-1.199)\end{array}$ \\
\hline ear, face and neck & 0.24 & 0.41 & $\begin{array}{c}1.277 \\
(0.879-1.794)\end{array}$ & $\begin{array}{c}0.126 \\
(0.07-0.207)\end{array}$ & $\begin{array}{c}0.458 \\
(0.433-0.484)\end{array}$ & $\begin{array}{c}0.157 \\
(0.144-0.171)\end{array}$ \\
\hline $\begin{array}{l}\text { congenital heart } \\
\text { defects }\end{array}$ & 5.86 & 10.48 & $\begin{array}{c}7.20 \\
(6.203-8.311)\end{array}$ & $\begin{array}{c}7.878 \\
(7.383-8.398)\end{array}$ & $\begin{array}{c}7.473 \\
(7.371-7.576)\end{array}$ & $\begin{array}{c}6.96 \\
(6.872-7.050)\end{array}$ \\
\hline respiratory & 0.38 & 0.35 & $\begin{array}{c}0.039 \\
(0.00-0.219)\end{array}$ & $\begin{array}{c}0.117 \\
(0.064-0.197)\end{array}$ & $\begin{array}{c}0.261(0.243- \\
0.281)\end{array}$ & $\begin{array}{c}0.334 \\
(0.315-0.354)\end{array}$ \\
\hline $\begin{array}{l}\text { cleft lip with or } \\
\text { without palate }\end{array}$ & 1.00 & 0.97 & $\begin{array}{c}1.161 \\
(0.783-1.658)\end{array}$ & $\begin{array}{c}0.804 \\
(0.651-0.981)\end{array}$ & $\begin{array}{c}0.854 \\
(0.820-0.889)\end{array}$ & $\begin{array}{c}0.726 \\
(0.697-0.755)\end{array}$ \\
\hline digestive system & 1.00 & 0.85 & $\begin{array}{c}1.084 \\
(0.720-1.566)\end{array}$ & $\begin{array}{c}1.348 \\
(1.148-1.573)\end{array}$ & $\begin{array}{c}1.627 \\
(1.579-1.675)\end{array}$ & $\begin{array}{c}1.558 \\
(1.516-1.601)\end{array}$ \\
\hline genital & 3.81 & 6.12 & $\begin{array}{c}0.735 \\
(0.443-1.149)\end{array}$ & $\begin{array}{c}2.369 \\
(2.102-2.662)\end{array}$ & $\begin{array}{c}2.090 \\
(2.036-2.145)\end{array}$ & $\begin{array}{c}2.108 \\
(2.059-2.157)\end{array}$ \\
\hline limb & 7.74 & 6.51 & $\begin{array}{c}4.103 \\
(3.360-4.962)\end{array}$ & $\begin{array}{c}4.638 \\
(4.260-5.041)\end{array}$ & $\begin{array}{c}4.781 \\
(4.699-4.863)\end{array}$ & $\begin{array}{c}3.691 \\
(3.627-3.757)\end{array}$ \\
\hline $\begin{array}{l}\text { including poly- } \\
\text { dactyly }\end{array}$ & 1.09 & 1.15 & $\begin{array}{c}1.123 \\
(0.752-1.612)\end{array}$ & $\begin{array}{c}1.407 \\
(1.202-1.636)\end{array}$ & $\begin{array}{c}0.859 \\
(0.825-0.894)\end{array}$ & $\begin{array}{c}0.915 \\
(0.883-0.948)\end{array}$ \\
\hline $\begin{array}{l}\text { chromosomal } \\
\text { abnormalities }\end{array}$ & 1.05 & 0.97 & $\begin{array}{c}1.123 \\
(0.752-1.612) \\
\end{array}$ & $\begin{array}{c}1.591 \\
(1.373-1.834)\end{array}$ & $\begin{array}{c}1.767 \\
(1.717-1.817) \\
\end{array}$ & $\begin{array}{c}1.689 \\
(1.646-1.733) \\
\end{array}$ \\
\hline $\begin{array}{l}\text { teratogenic } \\
\text { syndromes with } \\
\text { malformations }\end{array}$ & 0.50 & 0.85 & $\begin{array}{c}0.426 \\
(0.212-0.762)\end{array}$ & $\begin{array}{c}0.553 \\
(0.427-0.703)\end{array}$ & $\begin{array}{c}0.105 \\
(0.093-0.118)\end{array}$ & $\begin{array}{c}0.109 \\
(0.098-0.12)\end{array}$ \\
\hline Total & 24.75 & 31.4 & $\begin{array}{c}17.109 \\
(15.55-18.27)\end{array}$ & $\begin{array}{l}22.061 \\
(21.227- \\
22.920)\end{array}$ & $\begin{array}{c}22.740 \\
(22.562- \\
22.920)\end{array}$ & $\begin{array}{c}20.520 \\
(20.368- \\
20.674)\end{array}$ \\
\hline
\end{tabular}

diovascular system of children born alive (from $5.86 \%$ in $2001-2005$ to $10.48 \%$ in $2013-2017$ ) among the populations of Kherson region. Moreover, these indicators are significantly higher than the prevalence of this nosological form in Ukraine (7.2 and 7.88 respectively) and in European countries (7.47 and 6.96\% respectively). A similar trend is observed in the dynamics of the frequency of congenital malformations of the genital organs: an increase in the average annual indicator in Kherson region from 3.81 to $6.12 \%$ (in Ukraine - from 0.74 to $2.37 \%$ ), although in European countries this indicator has stabilized at the level of 2.09$2.11 \%$.

\section{Discussion}

Among all developmental anomalies the frequency of model forms and multiple defects is a sign that largely reflects the intensity of the mutation process in populations. Genetic factors and the mutational component (of at least $40 \%$ ) largely contributes to the etiology of multiple congenital malformations [9].
The prevalence of malformations in the populations of Kherson region is inversely correlated with the prevalence of spontaneous abortions $(r=-0.52 \pm 0.12 ; \operatorname{tr}=2.4>t 05=2.12)$, which indicates the "sifting" effect of natural selection that eliminates nonviable genotypes in the embryonic period of ontogenesis [10].

The increase in the prevalence of developmental anomalies in the region is mainly due to the increase in the frequency of model malformations recorded by the EUROCAT $(r=0.69, p<0.05)$. Fetal malformations that can affect the development of intrauterine and infant mortality and lead to human disability are called model congenital malformations or strict accounting malformations. They are highlighted by the EUROCAT for greater objectivity of research.

The prevalence of chromosomal abnormalities (1.0-1.17\%0) is characterized by relative stability, which confirms the previously stated assumption about the constancy of the level of the mutation process in the region. Among the nosological forms of chromosomal defects the 
largest specific weight is of Down syndrome $(83.7 \%)$ and a frequency of $0.9-1.02 \%$.

The frequency of malformations of the musculoskeletal system in Kherson region is 6.51-7.74\%o (in Ukraine and Europe 4.1-4.64\%o and 4.1-3.37\%o, respectively). In addition, an alarming trend was revealed of increased prevalence of multiple congenital malformations (from $0.5 \%$ to $0.85 \%$ ); their frequency significantly exceeds these indicators not only in Ukraine (0.43-0.55 \%o) but also in European countries (0.069-0.109\%).

The cluster of nosological forms of defects with a stable prevalence in Kherson region, which does not exceed the corresponding figure in Ukraine and European countries, should include malformations of the nervous system, congenital malformations of the face, neck, ears, cleft, lip and palate, other malformations of the digestive system, polydactyly (1.09\% in 2001-2005 and 1.15\% in 2013-2017; in Ukraine - 1.12 and $1.41 \%$; in European countries -0.86 and $0.92 \%$, respectively), chromosomal abnormalities (in Kherson region $1.05 \%$ and $0.97 \%$; in Ukraine -1.12 and $1.59 \%$; in European countries -1.77 and $1.69 \%$ respectively).

The prevalence of malformations of the respiratory system in Kherson region $(0.38 \% 0$ in 2001-2005 and 0.35\% in 2013-2017, respectively) significantly exceeds this level in Ukraine for the same period $(0.04 \% 0$ and $0.12 \%$, respectively) and is at the level of prevalence in European countries $(0.26 \%$ and $0.33 \%$, respectively).

\section{Conclusion}

The frequency of congenital malformations in Kherson region over the past 20 years is: for newborns - $31.57 \pm 1.25 \%$; for live births $31.38 \pm 1.11 \%$; for stillbirths $-197.7 \pm 0.65$ per 10.000. The increase in the prevalence of congenital malformations in the region is mainly due to an increase in the frequency of model malformations 6 which are subject to mandatory registration by the EUROCAT system ( $r=0.69$, $p<0.05$ ). In the structure of congenital malformations defects of the cardiovascular system $(31.77 \%)$, of the musculoskeletal system (25.14\%) and of genital organs (17.5\%) are leading. The frequency of malformations of the cardiovascular system, genitals and musculoskeletal system, multiple congenital malformations in Kherson region significantly exceeds the prevalence of these nosological forms in Ukraine and European countries. Among hereditarily determined forms the frequency of chromosomal abnormalities (1.0$1.17 \% 0$ ) is characterized by relative stability, which confirms our hypothesis about the constancy of the level of mutation process in the region. Among the nosological forms of chromosomal defects the largest share is for Down syndrome (83.7\%) with a frequency of 0.9-1.02. Reducing the burden of congenital anomalies in the population is possible through integration of research in epidemiology, genetic demography and epigenetics.

\section{Conflict of Interests}

Author declares no conflict of interest regarding this study.

\section{Acknowledgments}

The author expresses sincere gratitude to Svetlana Yevhenievna Onishchenko, a geneticist at Kherson Children's Clinical Hospital, for assistance in collecting primary medical and statistical material.

\title{
ДИНАМІКА ЧАСТОТИ ТА ОСОБЛИВОСТІ СТРУКТУРИ ВРОДЖЕНИХ ВАД РОЗВИТКУ НА ПІВДНІ УКРАЇНИ (МОНІТОРИНГОВЕ ДОСЛІДЖЕННЯ)
}

\author{
О. Лановенко \\ ХЕРСОНСЬКИЙ ДЕРЖАВНИЙ УНІВЕРСИТЕТ. ХЕРСОН. УКРАЇНА
}


Методи. Методи дослідження: епідеміологічний, медико-статистичний.

Отримані результати. У Херсонській області середня популяційна частота вроджених вад

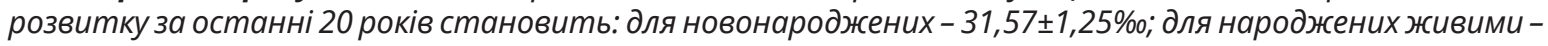

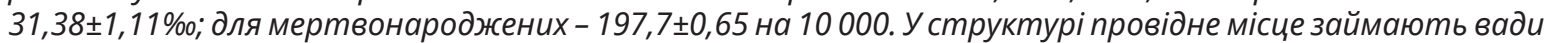
розвитку серцево-судинної системи (31,77\%). опорно-рухового апарату (25,14\%). статевих органів (17,5\%). Збільшення поширеності вроджених вад розвитку в регіоні в основному пов'язано зі збільшенням частоти модельних вад, що реєструються EUROCAT $(r=0.69$. $p<0.05)$. Підвищення загальної частоти вроджених вад відбувається за рахунок збільшення кількості народжених дітей з вадами серцевосудинної системи (на 4,67\%), статевих органів (на 1,21\%о), інших вад розвитку (на 1,55\%о), множинних вад (на 0,37\%).

Висновки. Результати моніторингу свідчать про зростання поширеності вроджених вад розвитку в Херсонській області за 20-річний період на 7,94\%. Причиною такого явища може бути скорочення чисельності населення через негативний природний і механічний приріст. Поширеність спадково обумовлених вад залишається на постійному рівні. У регіоні частота деяких нозологічних форм вад значно перевищує цей показник в Україні і країнах Європи: вад серцево-судинної системи - в 1,5 рази, статевих органів - майже в 3 рази, опорно-рухового апарату - майже в 2 рази. діти.

КЛЮчОВІ СЛОВА: вроджені вади розвитку; хромосомна патологія; популяція; новонароджені

\section{Information about the author}

Olena Lanovenko - Assistant Professor, Kherson State University, Ukraine ORCID: 0000-0003-1462-0967. e-mail: lanovenko2708@gmail.com

\section{References}

1. Bochkov NP. Clinical Genetics. 2th ed. Moskva: Geotar-Med; 2001. 448 p. [In Russian].

2. Zhuchenko LA, Letunovskaya AB, Demikova NS. The frequency and dynamics of congenital malformations in children in the Moscow region, according to the register of congenital malformations for the period 2000-2005. Rossiyskiy Vestnik Perinatologii i Pediatrii. 2008;53(2):30-8 [In Russian].

3. Hobbs CA, Chowdhury S, Cleves MA. Genetic epidemiology and nonsyndromic structural birth defects from candidate genes to epigenetic. JAMA Pediatrics. 2014; 168(4):371-77.

DOI: $10.1001 /$ jamapediatrics.2013.4858

4. Lanovenko OG. Dynamics of Congenital Development Disorders Prevalence in Ukrainian Regions and their Structure in Kherson Region . 2018; 12(2):45-2. [In Ukrainian].

DOI: $10.30970 /$ sbi.1202.561

5. Egbe A, Uppu S, Lee S, Stroustrup A, Ho D, Srivastava S. Congenital malformations in the new- born population: a population study and analysis of the effect of sex and prematurity. Pediatrics\&Neonatology.2015; 56(1):25-30.

6. Mikitenko DA. Ukraine: regional aspects of the genetic load of congenital and hereditary pathology. Sibirskiy Meditsinskiy Zhurnal. 2013; (3):18-3. [In Russian].

7. Community genetic services in Europe. Report on a survey: WHO. Copenhagen: European Services;1991. No 38. 147 p.

8. Minkov IP. Monitoring of congenital malformations: their prenatal diagnosis, role in pathology in children and ways of prevention. Perinatology and Pediatrics. 2000; (1): 8-3. [In Russian].

9. Lanovenko OG. Differentiation of local and rural populations of the Kherson region for the frequency of growth and development of reproductive costs. Visnyk Vinnyts'koho Natsional'noho Medychnoho Universytetu. 2018; 22(1):10-3. [In Ukrainian]. Received 31 May 2021; revised 20 Jun 2021;
accepted 23 Jun 2021

This is open access article distributed under the Creative Commons Attribution License, which permits unrestricted use, distribution, and reproduction in any medium, provided the original work is properly cited. 